\title{
FINANCIAL ANALYSIS OF THE POLITICAL PROPERTY OF NIZÂMÜL MÜLK
}

\author{
Recep TEMEL ${ }^{1}$
}

\begin{abstract}
Turks are one of the nations with the longest state experience in history.

It is of utmost importance that this experience accumulated in every aspect of the state life is brought to light and brought to the use of present-day statesmen.

One of the main sources of this knowledge and experience are the works written by the personalities who took an important role in the state life. One of these works is "Siyasetname" bir which is written by Nizâmül Mülk , who had worked for the Great Seljuk State for many years.

This study focuses on determining the financial issues discussed by Nizâmü'l Mülk in his work Siyasetname. In the light of these findings, it is aimed to transfer the historical knowledge and experience to the present day. The importance of the study will be put forward to the extent if these information and findings are generally taken into account in general by the state and in private by finance managers. This work containsinformation constitutionally about many different areas of state life. Within the scope of the scope of the study, firstly, the sections that focus on financial issues were chosen as the research area. These sections are discussed according to the method of screening, detection, analysis, criticism and composition which are commonly used in historical researches.
\end{abstract}

At the end of the study, it was found that sultans should behave those who were under the rule of the sultans with justice in any way, those who were governed should produce the public services they need, to supervise the other officials, especially the vizier, who serve the public, and to manage the treasury and income-expense transactions on a regular basis.

The most important result of these findings is the fact that operations in the financial structure and operation sensitivity of the state look alike regarding quantity and operates on an ongoing basis although 10 centuries passed away.

Keywords: Finance, Nizâmü'l Mülk, Book of government, financial inspection, public expenditures

JEL Code: B10, H10, H30.

\section{Introduction}

The fact that Turks have a deep-rooted history is in line with the richness of state management. Because it is a part of the state administration. It is unthinkable that this wealth does not effect the financial management understanding. One of the most important sources where this situation can be identified are the book of governments. These artifacts have often been written by personalities worked for the state on top level and which were well-known for their wise character. "Siyasetname" written by Nizâmü'l Mülk, who is the founder of the Nizamiye

1 Asst. Prof. Dr., Yozgat Bozok University, Faculty of Economics and Administrative Sciences, Department of Public Finance, recep.temel@bozok.edu.tr 
madrasas and vouched for the Seljuk rulers for many years, is one of this kind base work. The subject of this study is the determination of the financial issues discussed in Siyasetname. It is aimed to reveal the historical knowledge and experience in this field by means of these determinations. Even 10 centuries passed years since it was written, the determinations to be made will contribute to the understanding of today's financial management. The parts of the workcontaining information in different fields related to state administration covering the financial issues will be evaluated according to the screening, detection, analysis, criticism and composition methods which are widely used in historical research.

\section{Review}

"Siyasetname" considered among classical monuments has been the subject of research in many respects. Kafesoğlu evaluated the criticims in this work that this monument was not written by Nizamü'l Mülk and stated based on the fact that such a monument should only written by a person who worked over long years in the government existence that this work belongs to Nizamü'l Mülk and explained which subjects were discussed in the chapters of the work (Kafesoğlu, 1955: 231-256).

Şimşir emphasized the importance of security intelligence in state life and tried to identify how security intelligence was sensed by the state understanding of the period, its importance and the tools, places, methods and officials used in security intelligence (Şimşir, 2015: 68-79).

Eşmeli propounds that this monument is a book of politics because it contains basics also valid in the present politic life, that it is a book of theory in terms of containing practical proposals, a book of history in terms of containing historical events and personalities, a memoir containing personal memories and claims that it is a constitutional text because it contains information on rights and freedoms (Eşmeli, 2016: 145).

Özmen investigated the management philosophy in Siyasetname and as a result of his work he observed that Nizâmü "I Mülk recommended to the ruler in state administration, merit, justice, honesty and consultation; recommended that officers who will work in the central and provincial bureaucracy should remain within the rules of law and that they should take into account to fulfill the duty in consciousness (Özmen, 2014: 216).

Ocak, pointed out that the religious and intellectual life of Nizâmü“I Mülk was effected together with the educational understanding of the period he has lived and by the the political power dominant during his period (Ocak, 2018: 49),

Özaydın stated that Nizâmü"I Mülk has very great services in battles, in inter-state relations, in the struggle against those who want to cause chaos in the life of society, in the settlement of the ikta system, in the field of education, in the structure of the state and in zoning services (Özaydın, 2018: 1-31).

\section{General Information About Siyasetname}

In order to be able to evaluate the issues discussed in the policy, it is necessary to know the author of this work, Nizâmül Mülk closely. Then, the reasons for writing such a work should be emphasized. 


\subsection{The Life of Nizâmü’l}

Nizâmü'l Mülk was born on 10 April 1018 in the Nukan district belonging to the city Tus of Khorasan and died on 15 October 1092 in the Sinne region near Nihavend as a result of an attack on him (Arıcı, 2005: 21). His real name was Hasan b. Ali b. İshâk b. el-Abbas etTûsî'.

Nizâmü'l Mülk mother died when he was a baby and he had a good education due to the wealth of his father. He became at young age hafiz and and learned from famous wise persons hadis knowledge (Kesik, 2018: 58). Basicly of Persian lineage Nizâmü'l Mülk functioned as Vizier for 29 years at the Great Seljuk Empire during the times of Alp Arslan (1063-1072) and Melikşah (1072-1092) (Köymen, 2018). The name of Nizâmü'l Mülk (Organization of the Government) was given him by the Abbsai Khalifa El Kâim Bi Emrillah when he was attended as Vizier by Alp Arslan (Kesik, 2018: 58).

Nizâmü suretl Mulk wrote his experiences during his 29 years of his vizier time in the "Siyasetname" and conveyed the cases that administrators should take care for the stability of the state and the peace of society by giving examples in chapters. The work was written in Persian and consists of 52 chapters (Introduction and 51 Chapters).

\subsection{Reasons Why Siyasetname Was Written}

The reason why and for what purpose Siyasetname has been written is plained per se by Nizâmül Mülk in the introduction part of his work.

According to this information, in 1077-78 the Great Seljuk Sultan Melikshah asked the scholars and statesmen to write their thoughts about the state and the situation of society.

In doing so, he draws attention to determine the management understanding especially ha the Seljuk rulers uze the managers of other countries in the past, to determine what are the disruptions in society and state life and what kind of solutions are offered to them (Nizâmü'l Mülk, 1990: 1-2). Upon this request, Nizâmül Mülk explained that he recorded what he knows, what he sees, what he learns from experienced managers as a service.

He pointed out that he used in his every chapters hadiths, Qur'anic verses, the words of the elders, the stories they told, and his comments to prevent them from being bored while reading during the writing of his work.

Nevertheless, he mentioned that not any manager could not without this booklet, that it has to be read especially at the time when the work was written, and that if people read this book extremely they will be more vigilant in religion and world affairs, that they will appreciate the situation of their friends and enemies and take the necessary steps and he expresses assertively that that the life of the state and society would be much more regular (Nizâmü'I Mülk, 1990: 2-3).

\section{Financial Issues Discussed in Siyasetname}

Nizâmül Mülk explains in Siayasetname especially the characteristics that public officials should carry. He then reports on the tasks of these officials. It is possible to classify these tasks as administrative tasks and audit tasks. 


\subsection{Characteristics Public Officials have to Carry}

Hierarchically, starting from the sultans, the features of the financial officers are listed.

According to Nizâmü'l Mülk a Sultan has to be clean faced, morally justified, judicious, high minded besides he has to be intelligent in riding horses and using various weapons, talentent in different arts, compassive and mercy to Allah's creations, faithful to his words, religious and respective to religious people, helpful to arm people, affectionate against low level officers and servants and he has to be relentless against the oppressors (Nizâmü'l Mülk, 2010: 13).

Further the Sultan, "Neither he has to be stingy nor he has to be a dissipative that he will bring him the name dissipator." When the time comes, he should be bestow to everyone as much as it deserves (Nizâmü'l Mülk, 2010: 345).

The Vezir hould have a good nature, and certainly has not be bad tempered (Nizâmü'l Mülk, 2010: 29).

The task of the ministry should be given to someone who is totally insincerant of trust, and this person should be aware of the events in the dervish and should explain what he knows if needed (Nizâmü'l Mülk, 2010: 83).

Attendands like Amil, Kadi, Sahne and Muhtesip should be careful in keeping with the religious provisions, who always have fear of Allah and who do not have any hatred or hostility in their hearts (Nizâmü'l Mülk, 2010: 61).

\subsection{Community Services /Services Goverments Have to do}

The primary duty of the Sultan is to manage the ruled with justice and to ensure the safety of those who are obedient to the state and who are engaged in their own business (Nizâmü'l Mülk, 2010: 12).

In addition, he put in order that the sultan have also very important dutys in terms of in terms of public finances: " He makes the world flourishing. He opens canals for subterranean waters; he builds beds for streams, he builds bridges for the flow of large waters, arranges settlements, makes fields suitable for cultivation, raises walls, builds new cities, builds high buildings and majestic dwellings, hosts mansions on main and busy roads; orders the construction of madrasahs for science petitioners (Nizâmü'l Mülk, 2010: 12).

The Sultan also focuses on auditing tasks in order to ensure that financial affairs are carried out properly, and it is emphasized that those who are determined not to perform their duties properly should be punished (Nizâmü'l Mülk, 2010: 27-29)

\subsection{Public Officials - Taxpayer Relations}

Public revenues are one of the most important jobs in public finances. Public officials must be extremely sensitive during the execution of this task. In this respect, the issues which especially tax collectors have to observe during their duties are noteworthy: "They should be advised to be kind to Allah's servants, to postulate tributes and tithes with kindness, to nor demand goods from them as long as they do not collect their crops" (Nizâmü'l Mülk, 2010: 27). 
Further the notice to ikta owners like "People who are ikta owners have no right to take anything other than the goods they are asked to collect from them" (Nizâmü'l Mülk, 2010: 41) is very meaningful.

\subsection{Regulation of Public Revenues and Expenses}

In this regard, it is noteworthy to emphasize that income and expenses derived from provinces should be written in sums. Because, in a sense, it tries to determine whether there is an openness within the budget framework. in particular the following approch is a confirmation of this situation: "Endly, if someone has something to say or to make a saving his word should be respected, if he makes a justified request, the goods should be allocated. Thus, if there is an open or a deficiency in the account, it should be inspected immediately. Because this situation can not be strictly covered (Nizâmü'I Mülk, 2010: 345).

\section{Conclusion}

As a person who lived in the 11th century, the explanations of Nizâmü Mulk as a public servant in the financial organization of the state about the qualities especially of the sultan and the other officials under him should cover are very meaningful. It is noteworthy he expalins as a high graded manager that the sultan should have a justice-centered management understanding and that his subjects should take care to protect the law. In the same way, he requested to pay attention to the fact that those who were in the lower levels in a hierarchical manner should have high morality and it was recommended to keep their operations under constant supervision. In the sense that the law should be treated against the taxpayers of the period as they are the sources of public revenues, in a sense, it can be shown as evidence of the care taken to the rights of the taxpayer.

As a matter of fact, it is one of the most important warnings that the sultan should be sensitive against the taxpayers' complaints about financial issues and other issues. Comparison of revenues and expenses by recording public revenues and expenditures; taking into account the objections to the records, and if the objections are right the case has to met is evocative of budgetary implementations.

\section{References}

\section{Journals/Periodicals;}

Arıcı, H. (2005). "Nizâmü'l Mülk ve Selçuklu Müesseselerinin Oluşumundaki Yeri”, Ankara Üniversitesi, Sosyal Bilimler Enstitüsü, (Yayımlanmamış Yüksek Lisans Tezi), Ankara.

Eşmeli, B. (2016). "Siyasetname”, TESAM Akademi Dergisi, Cilt.3(2), ss. 139-145.

Kesik, M. (2018). “Büyük Selçuklu Devleti Veziri ve Türk Tarihinin Önemli Devlet Adamlarından Nizâmü'l Mülk (1018-1092)”, Selçuklu Araştırmaları Dergisi, Sayı.8, ss.53-81.

Kafesoğlu, i. (1955). “Büyük Selçuklu Veziri Nizâmü'l Mülk'ün Eseri Siyasetname ve Türkçe Tercümesi", Türkiyat Mecmuası, Cilt.12, ss.231-256. 
Köymen, M. A. (2018). "Büyük Selçuklu Veziri Nizâmü’l Mülk ve Tarihi Rolü" https://www. tarihtarih.com/?Syf=26\&Syz=367513\&/B\%C3\%BCy\%C3\%BCk-Sel\%C3\%A7uklu-VeziriNiz\%C3\%A2m\%C3\%BCl-M\%C3\%BClk-ve-Tarih\%C3\%AE-Rol\%C3\%BC-/-Prof.-Dr.-MehmetAltay-K\%C3\%B6ymen-, (26.02.2019).

Ocak, A. (2018). "Nizâmü'I Mülk'ün Dini ve Fikri Hayatı", Selçuklu Araştırmaları Dergisi, Sayı.8, ss.32-52.

Özaydın, A. (2018). “Nizâmü’l Mülk'ün Büyük Selçuklu İmparatorluğu’na Hizmetleri”, Selçuklu Araşttrmaları Dergisi, Sayı.8, ss.1-31.

Özmen, A. (2017). "Siyasetnamede Yönetim Felsefesi", Gümüşhane Üniversitesi Sosyal Bilimler Elektronik Dergisi, Cilt.5(10), ss.203-218.

Şimşir, M. (2015). "Nizâmü'l Mülk'ün Siyasetnamesi ve İstihbarata Yönelik Illke ve Yöntemleri", KMÜ Sosyal ve Ekonomik Araştirmalar Dergisi, 17(28), ss.68-79.

\section{Books;}

Nizâmü'I Mülk,(1990) , Siyasetname, Haz. M. Altay Köymen, İstanbul, Kültür Bakanlığı Yayınları.

Nizâmü’I Mülk, (2010), Siyasetname, Çev. Mehmet Taha Ayar, İstanbul, Türkiye İş Bankası Yayınları. 